Mut ĝ̣wĝ̀sith

JURNAL HUKUM ISLAM

\begin{tabular}{|l|l|l} 
Vol. 4. No. 1 (2021) 19-31 & E-ISSN: : 2723-4681 & P-ISSN: 2722-2764
\end{tabular}

Published online on the journal's website:

http://jurnal.iailm.ac.id/index.php/mutawasith

\title{
Marriage Affair In Islamic Law Anthropology Perspective
}

\author{
Teten Jalaludin Hayat \\ Institut Agama Islam Latifah Mubarokiyah Tasikmalaya, Indonesia \\ tj.hayat@gmail.com
}

\begin{tabular}{|c|c|c|}
\hline Received: & Revised: & Published: \\
\hline 09-02-2021 & 15-04-2020 & 05-07-2020 \\
\hline \multicolumn{2}{|c|}{ DOI: https://doi.org/ 10.47971/mjhi.v4i1.303 } \\
\hline
\end{tabular}

\begin{abstract}
The purpose of this study is to explain marriage affair or cheating in marriage as an anthropological review of Islamic law, thus, the legal wisdom should be obtained in addressing these problems. The Datas were obtained from scientific books and journals relating to the subject research theme. The research is library research, descriptive, and qualitative. The analysis technique used here was content analysis. Some of the findings research, that affair is a humanitarian epidemy that has existed throughout human history, even remains phenomenal today. Therefore, a legal wisdoms were needed in addressing these problems through the practice of religious teachings, thus the problems of cheating should suppressed and avoided, the ark of marriage can still be carried out on an ideal goal according to the anthropology of Islamic law.
\end{abstract}

Keywords: Affair, Anthropology, Islamic Law.

\section{A. INTRODUCTION}

The existence of Islamic teachings on earth is to give blessings, maslahat, and happiness to all humans (lil 'alamin), touching all areas of life, such as economy, work, and also marriage. In the field of marriage, it is not only directed towards biological satisfaction, but also emotional and spiritual satisfaction in the circle of sakinah, mawaddah, and rahmah, as a form of quality family. ${ }^{1}$

Undeniable, the life is so closely related to the changes of phenomena of the world, and everyone is constantly getting along with various changes in it. Thus such demands legal ijtihad to produce adaptive, implementative and transformational

\footnotetext{
${ }^{1}$ Muhamad Dani Somantri, Dahwadin Dahwadin, and Faisal Faisal, "Analisa Hukum Menunda Kehamilan Perkawinan Usia Dini Perspektif Istihsan: Sebuah Upaya Membangun Keluarga Berkualitas," Mahkamah: Jurnal Kajian Hukum Islam 3, no. 2 (November 1, 2018): 203-18, https://doi.org/10.24235/mahkamah.v3i2.3413.
} 
legal products, in line with the goals of Islamic universality. ${ }^{2}$ Especially through technological developments produced by industry 4.0 today, such globalization, automation, and digitalization of information and communication in various fields of life, made everyone being connected online anywhere and anytime. Especially in the current Covid-19 today, all activities should be laid off as much as possible to avoid the transmission of this pandemic. Automatically, the online facilities provided by Industry 4.0 are the only alternative that can be used to stay connected to the outside world. ${ }^{3}$

The industrial revolution 4.0 has indeed provided many conveniences and benefits in the experience of life, but there were also many mafsadats that may arise, especially in married life. Through online social media, such as Whatsapp, Facebook, Instragram, and others, everyone can connect with friends acquaintances beyond time. This situation, however, for unmarried person, these phenomenon were as blessing, so that they can seek and get acquainted with the opposite sex, and when they get a commitment to be more serious, they also legalize their relationship in the marriage contract. Additionally, these online relationship even has a negative impact on marriage, namely infidelity or marriage cheating. ${ }^{4}$

The phenomenon of infidelity in marriage is a historical phenomenon, long before the current globalization of communication. In the Koran there were also the information about this, where the wife of the Egyptian dignitaries, Siti Zulaikha, cheated on her husband with a handsome young man named Yusuf, even though Yusuf had a passion for the affair, but he did not actualize it. ${ }^{5}$ The same story also recurs in the story of Tenggelamnya Kapal Van Der Wijck (The Sinking of the Van Der Wijck Ship), a novel by the prominent Ulama, Hamka; where Hayati cheated on her husband, Aziz, with her longtime boyfriend, Zainudian; however, even though Zainudin still loved Hayati, he did not actualize it. ${ }^{6}$ The story in the Koran, and also Hamka's story earlier, is a description of the infidelity phenomenon that existed at

\footnotetext{
${ }^{2}$ Abbas Sofwan, "Interelasi Qowaid Usul Dan Fiqhiyah Sebagai Sebagai Landasan Hukum Islam Yang Universal," Legitima: Jurnal Hukum Keluarga Islam 1, no. 1 (December 27, 2018): 1-19, https://doi.org/10.33367/legitima.v1i1.640.

3 Abdul Ghofur and Bambang Subahri, "Konstruksi Sosial Keagamaan Masyarakat Pada Masa Pandemi Covid-19," Dakwatuna: Jurnal Dakwah Dan Komunikasi Islam 6, no. 2 (August 25, 2020): 281-301, https://doi.org/10.36835/dakwatuna.v6i2.636.

${ }^{4}$ Eko Harry Susanto and Silviana Dharma Zhang, "Critical Discourse Analysis of Interfaith Marriage News from Cyber Media in Indonesia," Journal of Educational and Social Research 7, no. 1 (January 8, 2017): 91.

${ }^{5}$ Ali Nurdin, "Etika Pergaulan Remaja dalam Kisah Nabi Yusuf AS: Telaah Tafsir Tarbawi dalam Surat Yusuf Ayat 23-24," Andragogi: Jurnal Pendidikan Islam dan Manajemen Pendidikan Islam 1, no. 3 (December 20, 2019): 490-510, https://doi.org/10.36671/andragogi.v1i3.69.

${ }^{6}$ Hidayah Budi Qur'ani, "Martabat Perempuan Minangkabau Dalam Novel Tenggelamnya Kapal Van Der Wijck Karya Hamka," Lingua Rima: Jurnal Pendidikan Bahasa Dan Sastra Indonesia 8, no. 1 (January 30, 2019): 9-17, https://doi.org/10.31000/lgrm.v8i1.1258.
} 
that time, that infidelity has indeed become a phenomenon of the times. For those who have watched gossip programs on television, such as Hot Shot, Insert, Celebrity, Razor Blade, Hot Kiss, Celeb Expose; or soap operas, films, and so on, often the shows in them are full of the phenomenon of infidelity. ${ }^{7}$

Frequently affair is considered as a poison that damages the marriage system, morever, this poisoning of cheating can be very deadly to the survival of married life. In any Religious Court (Pengadilan Agama) in Indonesia, such cases are never empty, mostly filed by wives through fasakh or khulu who reject their husband's infidelity and then sue for divorce. ${ }^{8}$

Indeed the notion that affair is a deadly poison for marriage is more widely understood by wives than husbands, especially in the Islamic or other legal traditions, it is forbidden for a wife to practice polyandry. On the other hand, a different perspective develops among husbands, where there is a kind of assumption that cheating is not something terrible, in fact, it is not uncommon for thinking that cheating is beautiful. It cannot be denied, because in the Islamic legal system there is a capacity for husbands to practice polygamy. ${ }^{9}$

After all, cheating in marriage really hurts the feelings of the couple. Whatever positive perspective is built on infidelity, the offense of the partner will undoubtedly make the household ark rock. Affair is like a big wave capable of overthrowing and sinking the marriage ark. Thus affair tends not to be of no benefits, and afterwards the purpose of marriage is straddled by sakinah, mawaddah, and rahmah.

In order to mediate various disagreements regarding the adultery in marriage, the Islamic law is required to be able to construct a building for its role, appearing as centripetal on marital problems. Anthropological studies in this regard are urgent to do, in an effort to bridge the gap between text and context, to adapt as well as to integrate it in married life, with the result that finally obtained anthropological products and legal policies. Therefore, the purpose of this study is to explain affair in an anthropological review of Islamic law in order to find legal wisdom.

\footnotetext{
7 Takdir Alisyahbana, "Hoax Dalam Perspektif Islam," El-Ghiroh : Jurnal Studi Keislaman 17, no. 02 (September 30, 2019): 103-25, https://doi.org/10.37092/el-ghiroh.v17i02.107.

8 Widya Timur and Dwi Putra Jaya, "TINJUAUAN HUKUM ISLAM DALAM PERKARA CERAI DENGAN ALASAN SALAH SATU PIHAK SELINGKUH DALAM MEDIA SOSIAL," Seminar Nasional Multi Disiplin Ilmu Universitas Asahan 0, no. 0 (October 16, 2020), http://jurnal.una.ac.id/index.php/semnasmudi/article/view/1583.

${ }^{9}$ Rahmin T. Husain et al., "Polygamy in the Perspective of Hadith: Justice and Equality among Wives in A Polygamy Practice," Madania: Jurnal Kajian Keislaman 23, no. 1 (July 7, 2019): 93-104, https://doi.org/10.29300/madania.v23i1.1954.
} 


\section{B. RESEARCH METHODS}

The research on affair in marriage in the review of the anthropology of Islamic law here is carried out using qualitative descriptive methods, because the data comes from scientific books and journals. Thus the this research is library research. The technique to collect datas is documentation. The technical analysis is content analysis. The expectation through this research can provide quality scientific contributions and conclusions.

\section{RESULTS AND DISCUSSION}

1. Research Results

Affair means being unfaithful or infidelity, hiding from the truth, or being embezzling money. Affair means that there is a content of lies, lies, dishonesty, overstepping mandates and straddling the truth. Acts of corruption, are included in the definition of affair, because they hide something from the true truth. If so, whatever the form of mandate violation, including the definition of affair. ${ }^{10}$

In marriage, affair is an act of insecurity in maintaining the sacred bonds and promises of marriage to be faithful forever. Infidelity is a form of betrayal that offends and hurts a partner, which in turn has the potential to pose a serious threat to the permanence of the marriage. It is not surprising that there are many divorce cases stemming from infidelity which is the main cause. ${ }^{11}$

There are several main causes of infidelity in marriage, both internal as well as external. Presumably, the most serious causative factor is spiritual ignorance, namely ignorance of understanding "before pinching others, pinch yourself first". If someone understands very well that if their partner cheating will hurt him, then of course he will not commit adultery. ${ }^{12}$

In some sources stated that the main factor of infidelity in marriage is ignorance of normative religious law. This argument can indeed be a strong argument for the occurrence of an affair. However, in reality, religious knowledge which is practiced only as limited as legal formal cannot be a guarantee of nonadultery. Not a few phenomena of a master of religious science who secretly

\footnotetext{
${ }^{10}$ Ari Kurniadi, Fauzi Muhammad, and Dian Mustika, "Faktor Terjadinya Perselingkuhan dalam Rumah Tangga" (skripsi, UIN Sulthan Thaha Saifuddin, 2019), http://repository.uinjambi.ac.id/1662/.

${ }^{11}$ Uswatun Hasanah and Chitra Latiffani, "The Factors Causing Early Divorce in Early Marriage," International Conference on Social, Sciences and Information Technology 1, no. 1 (September 3, 2020), https://doi.org/10.33330/icossit.v1i1.697.

${ }^{12}$ Christian Gullette, "Plato, Spiritual Marriage, and the Disruptive Potential of Queerness in August Strindberg's Giftas," Lambda Nordica 23, no. 1-2 (October 15, 2018): 39-61.
} 
cheated on his wife and carried out a secret marriage. This fact is not due to a lack of religious insight, but because of his spiritual weakness. ${ }^{13}$

In addition to the ignorance factor above, the disharmonious and intimate communication relationship between husband and wife, both physical and psychological, can also be a factor in causing an affair. A wife who has a very busy husband, then she feels bored with her marriage which is caused by a bad communication relationship, will be able to lead to an affair, especially the temptation to vent the saturation of communication is in its culmintaion. Likewise a husband, when he finds his wife does not show love and affection as expected, as if the dynamics of marriage are moving in a formal and boring manner, can also be an open path for an affair. ${ }^{14}$

Especially in the industrial era 4.0 today, the problem of marriage is increasingly complex, communication between humans is increasingly borderless. The incidents in the home as a household secret, can spread widely beyond ethical boundaries. The meetings with people from the past through online communication media seem to be a valuable opportunity to shed any boredom and stagnation that occurs in the household. Over time, the love flower that had been hidden for so long, blossomed again in a new romantic relationship, and then infidelity occurred. ${ }^{15}$

The problem of poverty and economic deprivation can be also being the cause of infidelity, especially in big cities with very strong hedonistic cultures. A beautiful wife, or a rich mighty husband, with a very hedonistic lifestyle, also far from faith, will easily get caught up in an affair. ${ }^{16}$

Infidelity in marriage is considered as behavior that deviates from the initial commitment of marriage, straddles trust, and is negative. However, undeniably, there another kind of affair is permitted, for example, for husbands in being the effort of polygamy. In the introductory process, it may appear that the husband is cheating on his wife. However, a husband's approach to other women is natural in polygamy, and should not be judged hastily as a form of illicit infidelity. Because, however, he has to know the character of his future wife, so that the introduction process takes place. If then the husband does this secretly from his previous wife,

13 Mohtazul Farid, "Hegemoni Patriarki dalam Poligami Kiai di Madura" (thesis, Universitas Airlangga, 2017), http://lib.unair.ac.id.

${ }^{14}$ Afgan Nugraha, Amiruddin Barinong, and Zainuddin Zainuddin, "Faktor Penyebab Terjadinya Perceraian Rumah Tangga AKibat Perselingkuhan," Kalabbirang Law Journal 2, no. 1 (May 14, 2020): 53-68.

15 Daniel Susilo and Eben Haezer, "Konstruksi Seksualitas Perempuan Dalam Berita Pemerkosaan Di Teks Media Daring," Jurnal Kawistara 7, no. 1 (October 5, 2017): 41-55, https://doi.org/10.22146/kawistara.15636.

${ }^{16}$ Halimahtun Saadiah, "Faktor-Faktor Sebab Terjadinya Perselingkuhan di Tempat Kerja (Studi Kasus Perkara-Perkara yang Masuk di Jabatan Agama Islam Perak)" (skripsi, UIN Ar-Raniry Banda Aceh, 2018), http://library.ar-raniry.ac.id. 
it cannot be said that the husband has betrayed his wife. It may be that the husband delays in telling the real matter at the right time, so that the wife really understands and is ready to accept the reality. In this case, of course, it is devoted to husbands who are indeed fit according to the Shari'a to carry out a polygamous marriage, for which he has met the requirements for polygamy.

Surely, the affairs that cannot be accepted and condemned by Islamic law is affairs committed by cheating by wives, affairs that harm their partners, affairs that contain elements of betrayal, and affairs that lead to adultery. An affair of a wife, because she is forbidden to do polyandry. An affair that is detrimental to the partner, contains elements of betrayal, morever if it leads to adultery, of course it is forbidden (haram), because such actions destroy commitments and violate the goals of marriage which are oriented towards sakinah, mawaddah, and rahmah.

\section{Discussion}

In the Islamic teaching system, any form of affair, if it contains elements of such hypocrisy, adultery, and infidelity, is punished by the Quran as a grave sin that will later be placed in the dayafter on the crust of hell. Some signs of hypocrisy (nifaq), namely when speaking being full of lies, when promising being full of denial, and when being trusted he is treasonous. ${ }^{17}$ Infidelity like this has the potential to destroy and lead a marriage to a painful divorce. Automatically, the purpose of marriage, which is full of sakinah, mawaddah, and rahmah, is being buried. ${ }^{18}$

However, in the Islamic marriage system, the most prohibited from cheating are the wives, because wives are prohibited doing as well as practicing polyandry (marrying more than one husband). ${ }^{19}$ Actually, this does not mean that husbands are perfectly allowed and without guilt to cheat on their wives and practice polygamy. There is a legal mechanism that a husband who wants to do polygamy must go through, as in Indonesia its mechanism has been stated in the 1974 Marriage Law and the Compilation of Islamic Law (KHI). ${ }^{20}$

Likewise, a form of adultery with treasonous and detrimental charges on the partner, especially that which leads to adultery, is a form of infidelity that is forbidden. Usually an affair with a charge like this is not intended to get benefit by

\footnotetext{
17 Burhan Tana, "Karakteristik Shalat Orang Munafik Dalam Al-Quran" (undergraduate, UIN Sunan Ampel Surabaya, 2018), http://digilib.uinsby.ac.id/24486/.

18 Somantri, Dahwadin, and Faisal, "Analisa Hukum Menunda Kehamilan Perkawinan Usia Dini Perspektif Istihsan: Sebuah Upaya Membangun Keluarga Berkualitas."

${ }^{19}$ Mohamed Ali et al., "Impact of Islamic Religion Stereotypes on the Status of Women," East African Journal of Arts and Social Sciences 1, no. 1 (September 23, 2019): 6-10.

${ }^{20}$ Gentur Cahyo Setiono and Achmad Bahroni, "Tinjauan Yuridis Tentang Poligami Tanpa Izin Isteri Menurut Kompilasi Hukum Islam (KHI)," Dinamika Hukum \& Masyarakat 1, no. 1 (April 11, 2020), https://doi.org/10.30737/dhm.v1i1.810.
} 
the perpetrator, instead only to indulge in lust and get a moment's biological pleasure, which actually leads to a bad ending. ${ }^{21}$

Along with the current rapid development of industrial technology 4.0, hedonistic materialism which has been developing so far, is becoming increasingly chaotic; a pragmatic and hedonistic secular lifestyle, increasingly irresistible. ${ }^{22}$ The attitude of life with religious and spiritual values is increasingly marginalized. There is a wide docotomy between mundane (secularistic) and religious (religiousspiritual) experience, where this dichotomy gives rise to the consequence that less religion interferes with human life, and over time, religion will be abandoned, its spiritual value becomes merely a completeness of formal legal identity, uprooted from life. ${ }^{23}$

When the authority of religion is deprived of the dimensions of life, such as in business, economics, communication, and other dimensions of life, religious violations become easier and without guilt to be carried out, and will even manifest as congregational prayer (cultural sin). In such circumstances, infidelity, in this case, becomes commonplace and is not considered a sin. No wonder, if there is a wife who doesn't mind her husband's infidelity, because she herself does it; vice versa. As a result, domestic life is completely independent of its religiosity and spirituality, and the purpose of marriage becomes bland, muspra, and mortal.

In any religion, the essence of man and humanity is not seen in the physical dimension, but in the spiritual. ${ }^{24}$ Worship of object, body, and beauty, will not bring true spiritual happiness. No matter how often a person satisfies his desire for love and affection through infidelity and betrayal, just like drinking sea water, the more thirsty he is drunk. ${ }^{25}$ This material lust satisfaction will never have an end, always thirst and thirst, so that it sinks and ends in disbelief and disregard for His provisions.

A person who is accustomed to cheating in his marriage, often considers his affair couple as true, good, and perfect; while the legal couple is considered ugly, flawed, and imperfect. Even some people who cheat feel a complete loss of love to their legal husband or wife. The eyes of his heart have been blinded by lust for a moment, so that he can no longer see the true truth, that his wife or husband is his

\footnotetext{
${ }^{21}$ Mulyadi Mulyadi and Muliono Muliono, "Tuduhan Zina di Media Sosial Perspektif Fiqh $\begin{array}{lllll}\text { Kontemporer," } \quad \text { IJTIHAD } & \text { 35, } & \text { (2019), }\end{array}$ https://journals.fasya.uinib.org/index.php/ijtihad/article/view/15.

22 Mulyadi and Muliono.

${ }^{23}$ Iim Suryahim, "Dzikir Dan Krisis Spiritual Manusia Modern," Jurnal Fakultas IImu Keislaman Kuningan 1, no. 1 (October 5, 2020): 40-45.

24 Suryahim.

${ }^{25}$ A. R. Idham Kholid, "Menuju Tuhan Melalui Tarekat: Kajian Tentang Pemikiran Tasawuf," JURNAL YAQZHAN: Analisis Filsafat, Agama Dan Kemanusiaan 4, no. 1 (June 1, 2018), https://doi.org/10.24235/jy.v4i1.3187.
} 
legal partner, and the one who should get more love and intimacy is his legal partner. ${ }^{26}$

Thus the new view has emerged that is not in line with Islamic law, even incompatible with universal human principles. The values of universality that will bring out the feminine character, have behaviors that tend to be more affectionate and attentive to others, subordinate all beyond her selfishness, like a mother who cares as well as loves for her children. There is no mother who cares more for someone else's child than her own child, except for a mother who is truly mentally and spiritually damaged. Likewise, when the perspective that is awakened to his legal husband or wife is lower than that of the affair, this is a sign of mental spiritual damage in them, as a result of past sins that have blinded the eyes of his heart.

It must be admitted, whatever the form of infidelity and betrayal, is almost unforgivable. However, from an anthropological perspective of Islamic law, a legal action must be found its 'illat, the origin of the problem. As in the ancient adage, there can be no smoke without fire. Likewise, in legal action in the form of adultery, the main reasons why the affair can occur, so that legal wisdom can be enforced afterwards as ibrah.

In the teachings of the Quran, there is not a single action that does not contain consequences or karma, both positive and negative actions. In al-Shura verse 40 , that the reward of badness is bad too. That is, someone who is cheating can only be a reflection of their cheating partner. Cheating wife, can be a reflection of the cheating husband; vice versa. The reply from cheating is cheating too. In alNur verse 26 it is explained that the bad (al-khabith) is for the bad (li al-khabith), and the good (al-thayyib) is for the good (li al-thayyib). It's just that, oftentimes, one is caught cheating, the other isn't caught; or, one is actualizing, and the other is only in the realm of ideas; in essence, the mentality of cheating remains in both.

However, Islamic law does not speak in the realm of discourse and idealism, Islamic law speaks in the realm of factual and realistic life. ${ }^{27}$ Another phenomenon that actually occurs in some societies, where marriages are held against the law of the Shari'a, namely without presenting witnesses, and that the witness is only Allah, because He is all-knowing and all-seeing. This, when viewed from the perspective of haqiqah, may be true, because God is all-things. However, this is of course not the jurisdiction of sharia, while marriage is not an act of haqiqah, but an act of shari'a. Therefore, the approach that must be used is the shari'a approach, not haqiqah. Such a marriage, which does not present a witness, is certainly not a valid

${ }^{26}$ Saadiah, "Faktor-Faktor Sebab Terjadinya Perselingkuhan di Tempat Kerja (Studi Kasus Perkara-Perkara yang Masuk di Jabatan Agama Islam Perak)."

27 Asep Usman, "Fenomena Tarekat Di Zaman Now: Telaah Atas Ajaran Dan Amalan TQN Suryalaya," Dakwah: Jurnal Kajian Dakwah Dan Kemasyarakatan 22, no. 2 (2018): 198-216, https://doi.org/10.15408/dakwah.v22i2.12068. 
marriage, and an intimate relationship between the two can be considered as zina in the Islamic legal system.

In the Sufi rules, as explained by Imam Malik, that figh (syari'ah) without tasawuf (haqiqah) is wickedness, tasawuf (haqiqah) without figh (syari'ah) is zindia (devil's deception), and the harmonious combination between fiqh and tasawuf is the true truth (tahaqqaqa). ${ }^{28}$ Therefore, marriage must be carried out in accordance with Sharia law, and must complete the pillars of marriage, including the presence of two witnesses; if one of the pillars of marriage is not fulfilled, marriage is considered void and invalid, the intimate relationship of both becomes adultery.

Such a view, that marriage is sufficient by Allah to be a witness, and there is no need to bring in zahir witnesses from among humans, is a dangerous perspective. Infidelity will easily occur, and marriage changes its orientation towards the satisfaction of biological lust.

The anthropology of Islamic law does provide legal wisdom that is adapted to evolving and changing realities. This does not mean that the reality of being a king freely controls the law. There are basic principles (ushul) that must not be violated, so that the internalization of the law does not have implications for the uprooting of the spirit of law (maqashid al-syari'ah).

The ability to realize and accept the current reality (ridha) can be a way out for legal complexities, including in matters of infidelity. Because often small problems become big, big problems get out of hand, resulting in lawlessness, starting from the inability to accept reality. A husband who does not accept the reality of his wife will look for other women who can satisfy his desires. A wife who does not accept the reality of her husband will look for other men who can satisfy her desires. If the inability to accept this reality is continuously developed, the irritation between the two of them in order to cover up and complement each other's shortcomings, will not be maintained.

Sometimes affair is regarded as a solution to the problem, in some people opinion. When examined more deeply, affair does not solve the problem at all, instead it adds to the problem. In superficial rationality, the perpetrator of an affair considers what he is doing as the best way he has been looking for forever, a way out of his various problems. Even though the truth he saw was very shallow, like a mirage (al-sarab) that looked like water in the distance, when approached there was absolutely no water. ${ }^{29}$ The affair may promise true beauty and happiness, but

28 Ahmad Syatori, "Tasawuf Di Antara Relasi Dan Relevansi," KACA (Karunia Cahaya Allah): Jurnal Dialogis Ilmu Ushuluddin 8, no. 2 (March 12, 2018): 209-22, https://doi.org/10.36781/kaca.v8i2.3017.

29 Siti Maisaroh, "Surah Al-Nur: Ditinjau Dari Potret Estetika Dan Ilustrasi Artistik Bahasa," Syaikhuna: Jurnal Pendidikan Dan Pranata Islam 8, no. 1 (October 4, 2017): 75-94. 
when the affair is actualized, she finds a reality that is far from hopeful. This often occurs as expectations that do not match reality, or reality that do not match expectations.

The ability to accept the reality of a partner is very important to know, understand, and realize in carrying out the marriage ark. Proportional and professional attitudes in the sense of properly understanding each other's capacities and potentials will greatly help to create alienation between partners. It is undeniable that in the household world there will always be problems in various aspects, including communication problems, economics, children's education, and so on. However, if a couple is ready to be distracted, any problem can be solved and a solution is found.

As long as a person only follows his lust, he will be constantly in trouble, there is no end to it. Will always be lacking and completely lacking. A rich person, will always feel less with his wealth, because he is still controlled by his lust. An artist, however beautiful his wife may not be able to see the beauty of his wife, and will see other people prettier than his wife, as long as this divine lust. Whatever problems in domestic life, they should not be the entrance to an affair, instead, these problems become a spiritual maturation of the household.

Thus, the religion must intervene in fostering the mentality of affair and controlling low lust, namely by truly practicing religion itself, not just as a discourse and theory that settles in the intellectual subconscious. Religion like this in no way provides self-transformation for the better, will not give a clear orientation to selfactualization, as long as religion only develops at the level of intellectual discourse. Religion must be sent down to earth in the form of real action, so that religion really gives color to his mentality and spirituality. Thus, affair and infidelity as a result of dissatisfaction with a partner metamorphoses into an attitude of alienation, whether in love, communication, romance, education, to intimacy.

\section{CONCLUSION}

Based on the explanation above, affair of marriage in the anthropological review of Islamic law is a humanitarian issue that is heavily criticized, as a form of commitment betrayal. There is not one person in the world who wants to be cheated on, and God doesn't want to be cheated on. Any anthropological problem can be resolved through legal wisdom. Legal wisdom is obtained through true practice of religious practice and experience, not just giving up legal obligations. The sign of wisdom is the ability to know, understand, and be aware of current realities, especially the realities of the couple. The basic principle in religion must be primary and primary in any legal action, and in responding to changes in any phenomenon. The law should not be manipulated only for momentary lust satisfaction, which actually leads to destruction. Any problem in the household, 
infidelity is not the best solution, it will exacerbate the existing problem. Except, if the legal action departs from legal wisdom, departs from positive irritation between partners.

\section{BIBLIOGRAPHY}

Ali, Mohamed, Ismail Abdul, Amina Wasifu, and Farida Chausiku. "Impact of Islamic Religion Stereotypes on the Status of Women." East African Journal of Arts and Social Sciences 1, no. 1 (September 23, 2019): 6-10.

Alisyahbana, Takdir. "Hoax Dalam Perspektif Islam." El-Ghiroh : Jurnal Studi Keislaman 17, no. 02 (September 30, 2019): 103-25. https://doi.org/10.37092/el-ghiroh.v17i02.107.

Farid, Mohtazul. "Hegemoni Patriarki dalam Poligami Kiai di Madura." Thesis, Universitas Airlangga, 2017. http://lib.unair.ac.id.

Ghofur, Abdul, and Bambang Subahri. "Konstruksi Sosial Keagamaan Masyarakat Pada Masa Pandemi Covid-19." Dakwatuna: Jurnal Dakwah Dan Komunikasi Islam 6, no. 2 (August 25, 2020): 281-301. https://doi.org/10.36835/dakwatuna.v6i2.636.

Gullette, Christian. "Plato, Spiritual Marriage, and the Disruptive Potential of Queerness in August Strindberg's Giftas." Lambda Nordica 23, no. 1-2 (October 15, 2018): 39-61.

Hasanah, Uswatun, and Chitra Latiffani. "The Factors Causing Early Divorce in Early Marriage." International Conference on Social, Sciences and Information Technology 1, no. 1 (September 3, 2020). https://doi.org/10.33330/icossit.v1i1.697.

Husain, Rahmin T., Arifuddin Ahmad, Siti Aisyah Kara, and Zulfahmi Alwi. "Polygamy in the Perspective of Hadith: Justice and Equality among Wives in A Polygamy Practice." Madania: Jurnal Kajian Keislaman 23, no. 1 (July 7, 2019): 93-104. https://doi.org/10.29300/madania.v23i1.1954.

Kholid, A. R. Idham. "Menuju Tuhan Melalui Tarekat: Kajian Tentang Pemikiran Tasawuf." JURNAL YAQZHAN: Analisis Filsafat, Agama Dan Kemanusiaan 4, no. 1 (June 1, 2018). https://doi.org/10.24235/jy.v4i1.3187.

Kurniadi, Ari, Fauzi Muhammad, and Dian Mustika. "Faktor Terjadinya Perselingkuhan dalam Rumah Tangga." Skripsi, UIN Sulthan Thaha Saifuddin, 2019. http://repository.uinjambi.ac.id/1662/.

Maisaroh, Siti. "Surah Al-Nur: Ditinjau Dari Potret Estetika Dan Ilustrasi Artistik Bahasa." Syaikhuna: Jurnal Pendidikan Dan Pranata Islam 8, no. 1 (October 4, 2017): 75-94.

Mulyadi, Mulyadi, and Muliono Muliono. "Tuduhan Zina di Media Sosial Perspektif Fiqh Kontemporer." IJTIHAD 35, no. 2 (2019). https://journals.fasya.uinib.org/index.php/ijtihad/article/view/15. 
Nugraha, Afgan, Amiruddin Barinong, and Zainuddin Zainuddin. "Faktor Penyebab Terjadinya Perceraian Rumah Tangga AKibat Perselingkuhan." Kalabbirang Law Journal 2, no. 1 (May 14, 2020): 53-68.

Nurdin, Ali. "Etika Pergaulan Remaja dalam Kisah Nabi Yusuf AS: Telaah Tafsir Tarbawi dalam Surat Yusuf Ayat 23-24." Andragogi: Jurnal Pendidikan Islam dan Manajemen Pendidikan Islam 1, no. 3 (December 20, 2019): 490-510. https://doi.org/10.36671/andragogi.v1i3.69.

Qur'ani, Hidayah Budi. "Martabat Perempuan Minangkabau Dalam Novel Tenggelamnya Kapal Van Der Wijck Karya Hamka." Lingua Rima: Jurnal Pendidikan Bahasa Dan Sastra Indonesia 8, no. 1 (January 30, 2019): 9-17. https://doi.org/10.31000/lgrm.v8i1.1258.

Saadiah, Halimahtun. "Faktor-Faktor Sebab Terjadinya Perselingkuhan di Tempat Kerja (Studi Kasus Perkara-Perkara yang Masuk di Jabatan Agama Islam Perak)." Skripsi, UIN Ar-Raniry Banda Aceh, 2018. http://library.arraniry.ac.id.

Setiono, Gentur Cahyo, and Achmad Bahroni. "Tinjauan Yuridis Tentang Poligami Tanpa Izin Isteri Menurut Kompilasi Hukum Islam (KHI)." Dinamika Hukum \& Masyarakat 1, no. 1 (April 11, 2020). https://doi.org/10.30737/dhm.v1i1.810.

Sofwan, Abbas. "Interelasi Qowaid Usul Dan Fiqhiyah Sebagai Sebagai Landasan Hukum Islam Yang Universal." Legitima: Jurnal Hukum Keluarga Islam 1, no. 1 (December 27, 2018): 1-19. https://doi.org/10.33367/legitima.v1i1.640.

Somantri, Muhamad Dani, Dahwadin Dahwadin, and Faisal Faisal. "Analisa Hukum Menunda Kehamilan Perkawinan Usia Dini Perspektif Istihsan: Sebuah Upaya Membangun Keluarga Berkualitas." Mahkamah : Jurnal Kajian Hukum Islam 3, no. 2 (November 1, 2018): 203-18. https://doi.org/10.24235/mahkamah.v3i2.3413.

Suryahim, lim. "Dzikir Dan Krisis Spiritual Manusia Modern." Jurnal Fakultas IImu Keislaman Kuningan 1, no. 1 (October 5, 2020): 40-45.

Susanto, Eko Harry, and Silviana Dharma Zhang. "Critical Discourse Analysis of Interfaith Marriage News from Cyber Media in Indonesia." Journal of Educational and Social Research 7, no. 1 (January 8, 2017): 91.

Susilo, Daniel, and Eben Haezer. "Konstruksi Seksualitas Perempuan Dalam Berita Pemerkosaan Di Teks Media Daring." Jurnal Kawistara 7, no. 1 (October 5, 2017): 41-55. https://doi.org/10.22146/kawistara.15636.

Syatori, Ahmad. "Tasawuf Di Antara Relasi Dan Relevansi." KACA (Karunia Cahaya Allah): Jurnal Dialogis IImu Ushuluddin 8, no. 2 (March 12, 2018): 209-22. https://doi.org/10.36781/kaca.v8i2.3017. 
Tana, Burhan. "Karakteristik Shalat Orang Munafik Dalam Al-Quran."

Undergraduate, UIN Sunan Ampel Surabaya, 2018.

http://digilib.uinsby.ac.id/24486/.

Timur, Widya, and Dwi Putra Jaya. "TINJUAUAN HUKUM ISLAM DALAM PERKARA CERAI DENGAN ALASAN SALAH SATU PIHAK SELINGKUH DALAM MEDIA SOSIAL." Seminar Nasional Multi Disiplin IImu Universitas Asahan 0, no. 0 (October 16, 2020).

http://jurnal.una.ac.id/index.php/semnasmudi/article/view/1583.

Usman, Asep. "Fenomena Tarekat Di Zaman Now: Telaah Atas Ajaran Dan Amalan TQN Suryalaya." Dakwah: Jurnal Kajian Dakwah Dan Kemasyarakatan 22, no. 2 (2018): 198-216. https://doi.org/10.15408/dakwah.v22i2.12068. 